\title{
Impact of Recycling Cleaning Solution under Cleaning-In-Place (CIP) System on Thermoduric Count in Pasteurized Milk
}

\author{
Amitha Thomas*, V. Prasad, P.M. Priya, C.T. Sathian and R. Geetha
}

Kerala Veterinary and Animal Sciences University, India

*Corresponding author

\section{A B S T R A C T}

\section{Keywords \\ Cleaning solution, CIP system, Thermoduric bacteria, Pasteurization \\ Article Info \\ Accepted: \\ 12 May 2019 \\ Available Online: \\ 10 June 2019}

\section{Introduction}

Thermoduric bacteria are organisms capable of surviving the industrial pasteurization process of milk, and can carry over into product causing quality defects, or creating health hazards. The various species of genus Bacillus, Microbacterium, Micrococcus, Enterococcus, Lactobacillus and Corynebacterium are described as heat resistant species (Marth and Steele, 2001). Laboratory pasteurization count (LPC) will give an idea about the thermoduric organisms present in the milk (Quin and Burgwald, 1933) and reflects the sanitation level during milking and the adequacy of the milking system cleanup between milking periods (Wirtanen and Salo, 2003).

The soil bank system is a type of CIP system where the alkaline solution is recovered in a large alkaline tank for reuse up to one week (Tamime, 2008). This system is essential to economize the cleaning procedures in a processing plant (Gracia and Diaz, 2011). However the repeated use of cleaning solution may build up the thermoduric organisms in the solution. This may subsequently act as a source of contamination of pipelines especially building microflora in the dead 
ends of pipelines (Genevihe et al., 2002). Timely revision of cleaning strategies in dairy plants is also essential for maintaining good product quality (Vlkovai et al., 2008). Reusing of alkali solution of CIP system may contribute to increase of thermoduric count in pasteurized milk especially the acid and alkali adapted organisms (Alvarez et al., 1998).

If the bacterial count in pasteurized milk is not being influenced beyond the specified limits by reuse of CIP solution, then it would be possible to increase the frequency of reuse to economize the operation.

\section{Materials and Methods}

\section{Preparation of alkali solution for CIP and cleaning}

The alkali solution for the reusability study was prepared using in water to make a final concentration of 1.5 per cent. Each prepared samples were reused for once by keeping the concentration of sodium hydroxide not below 0.5 per cent. The solution once used was discarded after the second day of use because of the presence of milk soil particles. New lot of solutions was prepared for the subsequent day of cleaning.

\section{Collection of samples}

The samples from pooled raw milk were collected immediately after milking from the farm, just before pasteurization from Dairy Plant and pasteurized milk immediately after HTST pasteurization and packaging. Alkali solution intended for CIP cleaning were collected before and after use on each day. The surface swab of milk storage tank was collected after CIP cleaning. The guidelines explained in Standard methods for the examination of dairy products (Wehr and Frank, 2004) were adapted for the collection of samples.

\section{Bacterial count}

Total viable count of each sample was estimated by pour plate technique, as described by Mortan (2001) and counts were expressed as $\log _{10} \mathrm{cfu} / \mathrm{ml}$. To determine the thermoduric count, the samples were subjected to laboratory pasteurization at $63^{0} \mathrm{C}$ for 30 minutes (Wehr and Frank, 2004). After laboratory pasteurization the samples up to $3^{\text {rd }}$ dilution were plated for the enumeration of thermoduric count to the standard plate count agar.

\section{Isolation and identification of bacteria}

All samples of pooled raw milk, fresh pasteurized milk, alkali solution for cleaning and swab sample of storage tank were subjected for the isolation and identification of thermoduric bacteria. Identification of the bacterial isolates was performed based on their morphological, physiological, and biochemical characteristics, as described in Bergey's Manual of Systematic Bacteriology (Claus and Berkeley, 1986) and it is shown in the Flow chart 1. Polymerase Chain Reaction was conducted for the detection of thermoduric bacilli by the method as described by Joo et al., (2007).

\section{Acid alkali and heat adaptation studies}

For acid adaptation studies $\mathrm{pH}$ of nutrient broth were adjusted with $1 \mathrm{~N}$ Hydrochloric acid $(\mathrm{HCl})$ to $4.9,5.5$ and 6.3. For alkaline adaptation studies $\mathrm{pH}$ of nutrient broth were adjusted with $1 \mathrm{~N} \mathrm{NaOH}$ to $8.5,9.5$ and 10.5 and for heat adaptation studies the overnight broth cultures were inoculated into nutrient broth at 1 per cent level and subjected to different heat treatments $65^{\circ} \mathrm{C}, 70^{\circ} \mathrm{C}$ and $80^{\circ} \mathrm{C}$. The tubes were inoculated with one per cent of the above prepared overnight broth culture. Enumeration (Mortan 2001) of the prepared samples was carried out at $0,15,30$, 
45 and 60 minutes of incubation at room temperature. The growth rate $(\mathrm{cfu})$ of each isolate at each $\mathrm{pH}$ and temperature was calculated and plotted as a function of time (Lindsaya et al., 2000).

The data obtained from the various studies were subjected to statistical analysis following procedure described by Snedecor and Cochran, 1994.

\section{Results and Discussion}

Hygienic handling of milk during the various stages of its production, transportation and subsequent pasteurization and storage at refrigeration play a significant role in quality assurance of fluid milk. In this study the effect of reuse of cleaning solution on the total viable count (TVC), thermoduric count and type of thermoduric organisms prevailed in the samples were studied.

\section{Bacterial counts}

The bacterial quality of different samples like milk, alkaline cleaning solution and surface swab of storage tank were evaluated by estimating the total viable count and thermoduric count (Table 1). The TVC of raw milk immediately after milking was $5.30 \pm$ $0.46 \log _{10} \mathrm{cfu} / \mathrm{ml}$ and it is in accordance with the findings of Prejitet al., (2007). The TVC of the raw milk collected just before pasteurization was greater than $6 \log _{10} \mathrm{cfu}$ $/ \mathrm{ml}$ and the increase in count may be due to keeping of the raw milk without chilling before pasteurization (Meanwell, 1939). The mean total viable count of the pasteurized milk samples after the first day of cleaning was $4.68 \pm .20 \quad \log _{10} \mathrm{cfu} / \mathrm{ml}$ and after the second day it was $4.74 \pm 0.30 \log _{10} \mathrm{cfu} / \mathrm{ml}$. The count obtained in the present study is in agreement with the counts reported by Pelezynska and Libett (1995), Beloti et al., (2002), and Prejitet al., (2007) for pasteurized milk. Sethulakshmi et al., (2003) has reported a TVC of $2.82 \pm 0.14 \log _{10} \mathrm{cfu} / \mathrm{ml}$ in pasteurized milk. Latha and Nanu (1997) reported a TVC of $5.57 \pm 0.06 \log _{10} \mathrm{cfu} / \mathrm{ml}$ from pasteurized milk. The variations in the TVC obtained in the present study could be due to the difference in location, treatments given, types of samples, and hygienic measures taken during production, transport, handling and processing of milk in the dairy plant. No statistical significant difference was observed in the TVC of pasteurized milk on reuse of alkaline cleaning solution and the count was under the limits stipulated by Indian standards. The mean TVC of cleaning solution immediately after preparation on the first day was $1.60 \pm 0.31 \log _{10} \mathrm{cfu} / \mathrm{ml}$ and after cleaning it was $1.63 \pm 0.28 \log _{10} \mathrm{cfu} / \mathrm{ml}$. On the second day of cleaning the TVC before cleaning was $1.58 \pm 0.22 \log _{10} \mathrm{cfu} / \mathrm{ml}$ and after cleaning it was $1.62 \pm 0.43 \log _{10} \mathrm{cfu} / \mathrm{ml}$. This slight reduction in the TVC observed in the used solution, might be due the destruction of organisms by combined effect of heat and alkali during the CIP procedures. The TVC from the internal surface swab of the milk storage tank after cleaning on the first day was $1.71 \pm 0.22 \log _{10} \mathrm{cfu} / \mathrm{ml}$ and on the second day after cleaning was $1.75 \pm 0.68$ $\log _{10} \mathrm{cfu} / \mathrm{ml}$. The count is within the limit as stipulated by standard of American Public Health Association (Rice, 1960). A slight increase in the TVC on the second day might be due to the reduction in the alkaline concentration of cleaning solution due to reuse.

The thermoduric count of raw milk immediately after milking was $3.74 \pm 0.11$, and the count obtained just before pasteurization was $5.52 \pm 0.24 \log 10 \mathrm{cfu} / \mathrm{ml}$. The count in the present study is one log lesser than the findings of Quin and Burgwald (1933). The thermoduric count of the raw milk collected just before pasteurization was significantly increased to $5.52 \pm 0.24 \log 10$ 
cfu $/ \mathrm{ml}$. This increase could be attributed to the delay in processing of milk to an extended period of four hours without refrigeration. The studies of Grange and Nelson in 1961 revealed that in 47 per cent milk sample, the thermoduric count of raw milk was in the range of 10000-100000 cfu/ $\mathrm{ml}$ which correlates with the results of the current study.

The mean thermoduric count of pasteurized milk samples after the first day of cleaning was $4.09 \pm 0.56 \log _{10} \mathrm{cfu} / \mathrm{mland}$ the second day it was $4.12 \pm 0.97 \log _{10} \mathrm{cfu} / \mathrm{ml}$. The count in the samples under the current study was similar to that reported by Yale in 1933 and Prucha and Parfitt in 1938. The count observed in the present study was one log higher than that recorded by Grang and Nelson (1961). The mean thermoduric count of the alkaline cleaning solution immediately after preparation on the first day was $1.02 \pm$ $0.04 \log _{10} \mathrm{cfu} / \mathrm{ml}$ and after cleaning it was $1.09 \pm 0.09 \log _{10} \mathrm{cfu} / \mathrm{ml}$. On the second day of cleaning the mean thermoduric count before cleaning was $1.09 \pm 0.15 \log _{10} \mathrm{cfu} / \mathrm{ml}$ and after cleaning it was $1.12 \pm 0.17 \log _{10} \mathrm{cfu} / \mathrm{ml}$. The slight increase in the thermoduric count after cleaning shows the adaptability of the organisms to grow at high temperature and alkaline conditions. The thermoduric count of the bacteria from the internal surface swab of the milk storage tank after cleaning on the first day was $1.17 \pm 0.26 \log { }_{10} \mathrm{cfu} / \mathrm{ml}$ and on the second day was $1.19 \pm 0.34 \log _{10} \mathrm{cfu} / \mathrm{ml}$. The slight increase in the thermoduric count of surface swab sample might be due to the reduction in the alkaline concentration of cleaning solution due to reuse.

Fig.1 Growth curve of acid adapted organisms

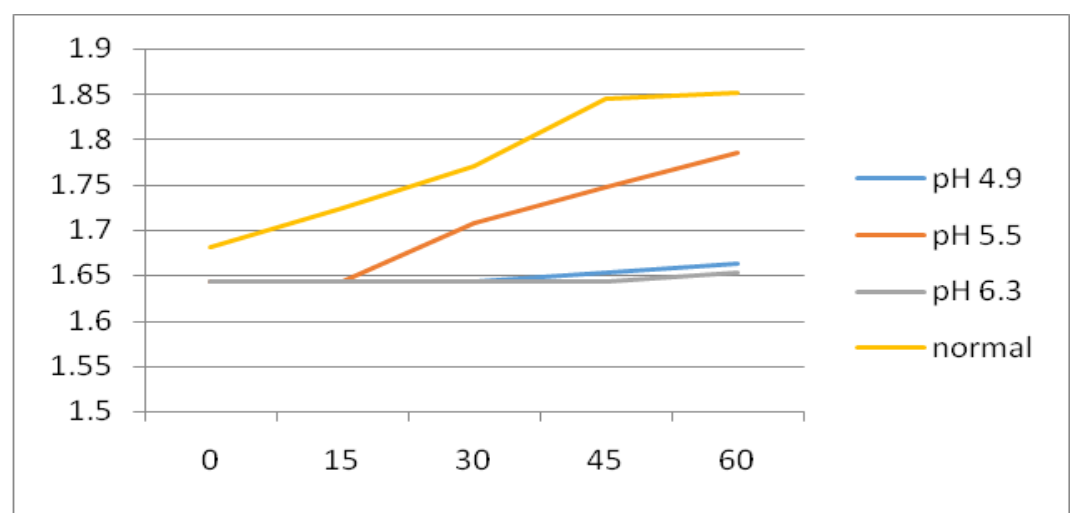

Fig.2 Growth curve of alkali adapted organisms

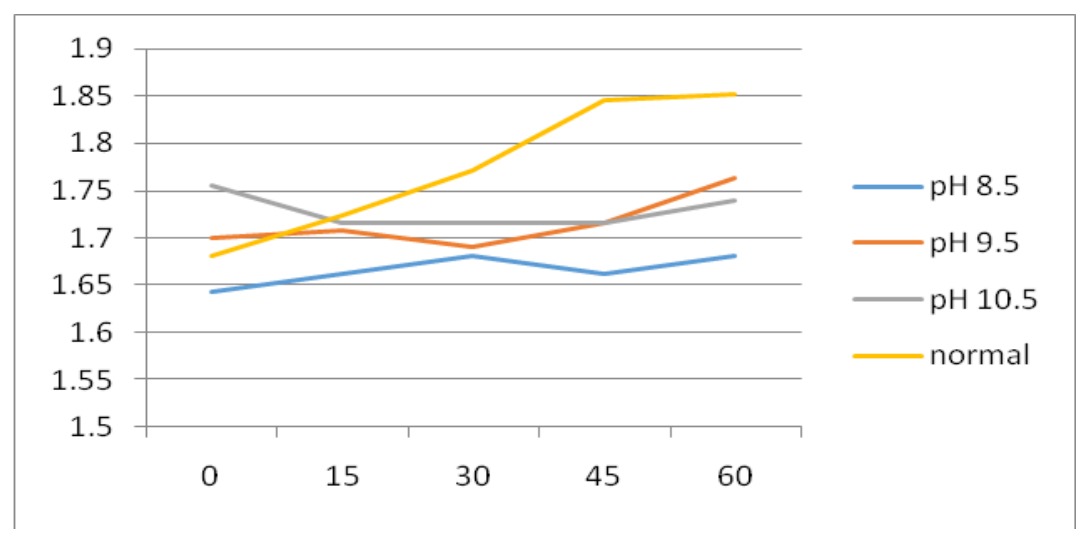


Fig.3 Growth curve of heat adapted organisms

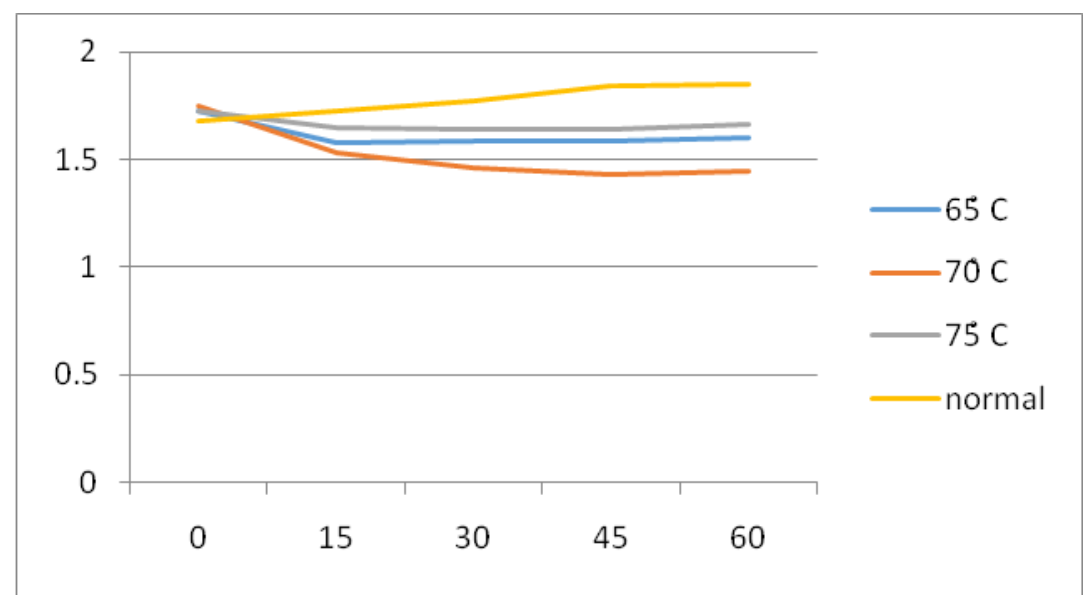

Table.1 Bacterial counts of different samples (Mean \pm SE in $\log _{10} \mathrm{cfu} / \mathrm{ml}$ )

\begin{tabular}{|c|c|c|c|c|c|c|}
\hline Count & Day & Raw milk & $\begin{array}{c}\text { Pasteurized } \\
\text { milk }\end{array}$ & \multicolumn{2}{|c|}{ Cleaning solution } & Surface swab \\
\cline { 4 - 7 } & & & & & \\
\hline Total viable & 1 & $5.30 \pm 0.46$ & $4.68 \pm 0.2$ & $1.58 \pm 0.22$ & $1.60 \pm 0.31$ & $1.71 \pm 0.22$ \\
\cline { 3 - 7 } count & 2 & & $4.74 \pm 0.3$ & $1.62 \pm 0.43$ & $1.63 \pm 0.28$ & $1.75 \pm 0.68$ \\
\hline $\begin{array}{c}\text { Thermoduric } \\
\text { count }\end{array}$ & 1 & $3.74 \pm 0.11$ & $4.09 \pm 0.56$ & $1.09 \pm 0.09$ & $1.02 \pm 0.04$ & $1.17 \pm 0.26$ \\
\cline { 3 - 6 } & 2 & & $4.12 \pm 0.97$ & $1.12 \pm 0.17$ & $1.09 \pm 0.15$ & $1.19 \pm 0.34$ \\
\hline
\end{tabular}

Table.2 Detailed identification of isolates

\begin{tabular}{|l|l|}
\hline Test & Result \\
\hline Morphology & Bacilli \\
\hline Gram staining & positive \\
\hline Spores & positive \\
\hline Motility & negative \\
\hline Catalase & positive \\
\hline Citrate utilization & Positive \\
\hline Oxidase & negative \\
\hline Urease activity & negative \\
\hline Methyl Red & positive \\
\hline Gelatin Liquefaction & Positive \\
\hline VogesProskauer & negative \\
\hline Mannitol Reduction & Positive \\
\hline Indole production & negative \\
\hline Aesculin hydrolysis & positive \\
\hline Starch hydrolysis & positive \\
\hline
\end{tabular}


Flowchart 1. Isolation and Identification of Thermoduric Bacillus(Claus and Berkeley, 1986).

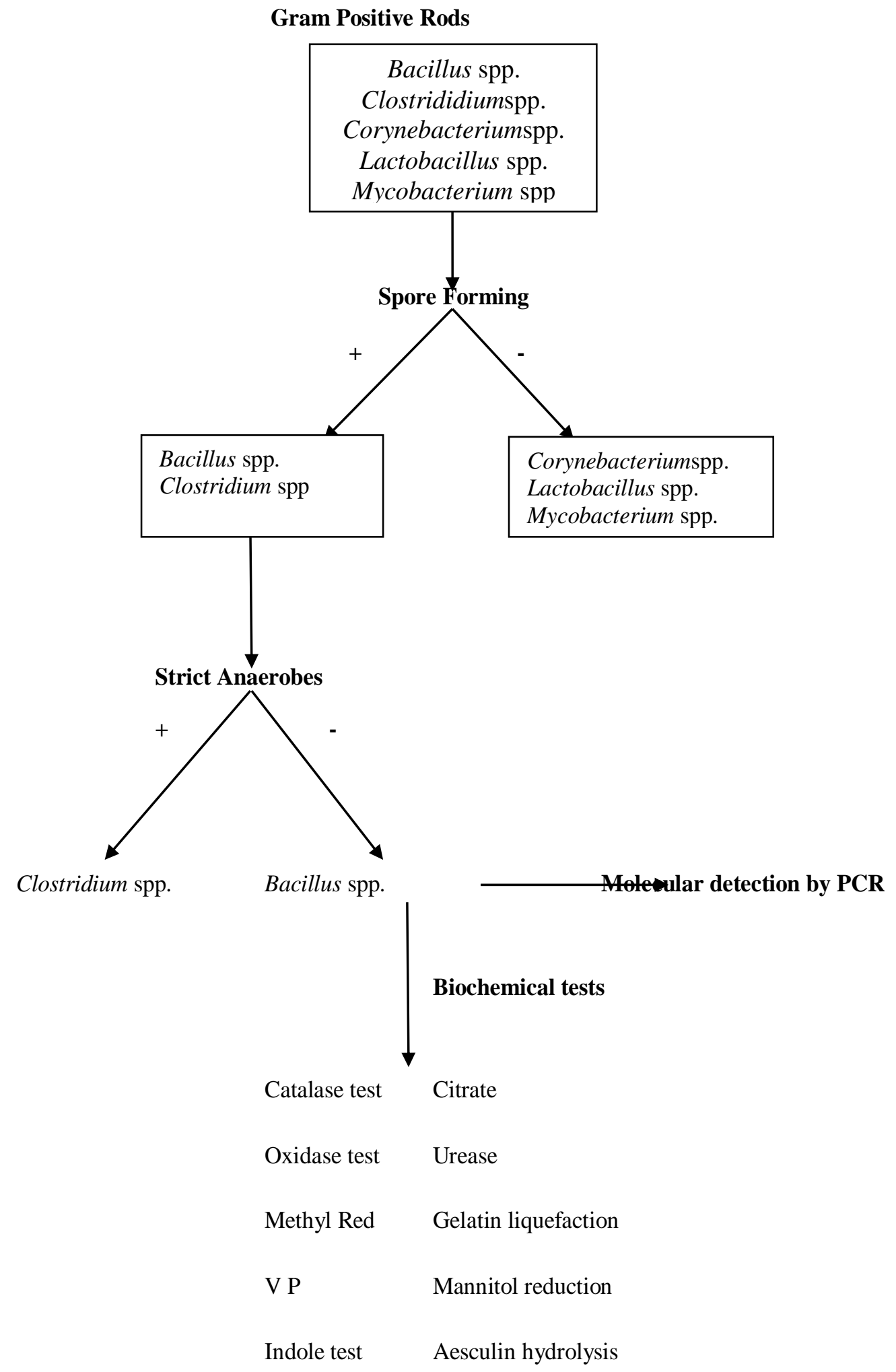


All the raw milk samples immediately after milking was under the very good range, according to the specifications of Indian Standard Institution (ISI, 1977). However the raw milk immediately before pasteurization had a substantial increase in both TVC and thermoduric count and is classified as poor category. This could be attributed to the keeping of milk at room temperature without chilling. The TVC of pasteurized milk obtained was $5.30 \pm 0.46 \log _{10} \mathrm{cfu} / \mathrm{ml}$ and is well above the advisable level as stipulated by BIS (ISI 1977). The thermoduric count of the raw milk immediately after milking was 3.74 $\pm 0.11 \log _{10} \mathrm{cfu} / \mathrm{ml}$ and count of $5.52 \pm 0.24$ $\log _{10} \mathrm{cfu} / \mathrm{ml}$ be observed immediately before processing. The thermoduric count of the pasteurized milk was under the fair category specified by ISI 1977. There is a significant difference was observed in the commercial pasteurization and laboratory pasteurization counts. One of the possible reason for the elevated count is the post pasteurization contamination of the milk. On statistical analysis there is no significant difference observed between thermoduric counts of pasteurized milk by reuse of the alkaline cleaning solution.

\section{Isolation of thermoduric bacteria}

Milk serves as an excellent medium for the growth of certain microorganisms whose multiplication is mainly dependent on temperature and on competing microorganisms and their metabolic products. Some thermoduric organisms plays a significant role in consumers health and in spoilage of milk. The most commonly found thermoduric organisms in milk and dairy environment are the different species of Bacillus and Clostridium.

The thermoduric bacteria isolated from the samples were grown into the nutrient agar and identified by morphology, cultural characteristics, biochemical reactions and by PCR. A total of 128 samples were obtained, out of which 40 isolates belongs to the thermoduric bacterial genus Bacillus. The isolated organisms were Gram positive Bacillus with an endospore and a capsule. The organisms were aerobic in nature. According to the results obtained from biochemical reactions (Table 2) the isolates were identified as $B$. megaterium. The genus specific $16 \mathrm{~S}$ rRNA PCR was done using 27f and 1492r primers. Fourty samples of Bacillus megaterium characterized by biochemical tests were subjected to PCR and gave an amplification of $1.4 \mathrm{~Kb}$ size corresponding to the genus which correlates with the findings of Joo et al., (2007). The present observation is in concurrence with the report of Frank, 1997 and Faille et al., 2001. The studies of Shaheen et al., (2006) showed that the predominant species of thermoduric Bacillus in milk and dairy products is $B$. cereus.

The growth of the isolates at different $\mathrm{pH}$ and temperature were indicated that the maximum inhibition of the growth of the organisms were at pH 6.3 (Fig. 1) and 8.5 (Fig. 2), and temperature $70^{\circ} \mathrm{C}$ (Fig. 3). This is similar to the findings of Lindsaya et al., (2000). So for maximum cleaning efficiency the above concentrations and temperature can be used.

It is concluded that cleaning In Place system in a Dairy Plant consist of the use of various types of detergents, sanitizers or disinfectants for cleaning and these agents can be stored and reused for the cleaning on next day. This system will economize the cleaning procedures in a processing plant, but repeated use may cause the buildup of thermoduric organisms in the pipelines and subsequently in to the pasteurized milk. So timely revision of the cleaning strategies should be carried out to obtain good product quality. In the present study the effectiveness of reusing the alkaline CIP solution was carried out by 
determining both the TVC and thermoduric count of pasteurized milk. The results of this study has indicated that reuse of alkaline solution in the CIP system has not affected the thermoduric count in pasteurized milk suggesting the safety in its reuse. There is significant increase in the thermoduric count observed in the plant pasteurized milk when compared to the laboratory pasteurized milk which indicates inadequate pasteurization temperature or post pasteurization contamination. The isolated thermoduric bacteria have been shown to be $B$. megaterium. The high level of TVC in the raw milk before processing highlights the importance of chilling at farm level or immediate processing of milk after production. For the maximum inhibition of the $B$. megaterium which is predominant in the various milk samples tested, it is recommended to use minimum of $70^{\circ} \mathrm{C}$ for its destruction. The preferred $\mathrm{pH}$ for alkaline and acid cleaning solution was found to be 8.5 and 6.3 respectively.

\section{References}

Alvarez, S., N. Gobbato, E., Bru, A. P., Holagdo, D.R. and Perdigon, G. 1998. Specific immunity induction at the mucosal level by viable Lactobacillus casei, A perspective for oral vaccine development. Food Agri. Immunol. 10:79-87

Beloti, V., Barros, M.A.F., Nero, L.A., Pachemshy, H.A.S., Santana, E.H.W. and Franco, B.D.G.M. 2002. Quality of pasteurized milk influences the performance of ready to use systems for enumeration of aerobic microorganisms. Int. Dairy J. 12: 413-418

Claus, D. and Berkeley, R.C.W. 1986 Genus Bacillus. In Bergey's Manual of Systematic Bacteriology. pp 1105-1120

Faille, C., Fontaine, F., and Benezech, T. 2001. Potential occurrence of adhering living Bacillus spores in milk product processing lines. J. Applied Microbiol. 90: 892-900

Frank, J.F. 1997. Milk and dairy products. In: Doyle, M.P., Beuchat, L.R., Montville, T.J. (Eds.), Food Microbiology: Fundamentals and Frontiers, ASM Press, Washington, DC, pp. 101-116

Genevihe, G., Guiziouil, A., Boyavalb, E. and Daufinc, G. 2002. Nanofiltration for the recovery of caustic cleaning-in-place solutions: robustness towards large variations of composition. Desalination. 49:127-129

Gracia, M and Diaz, M. 2011. Cleaning in place. Comprehensive Biotechnol. 2:983-997

Grange, W. S. and Nelson, F. E. 1963. Bacteriological evaluation of manufacturing grade bulk tank milk. Quensland Agri. J. 11:440-445

Indian standard. 1977. IS: 1479. Methods for text for dairy industry. Part III. Bacteriological analysis of milk (First revision). Bureau of Indian Standards, ManakBhavan, 9, Bahadur Shah Zafar Marg, New Delhi - 1.p.25

Joo, M. H., Hur, S. H., Han, Y. S. and Kim, J. Y. 2007. Isolation, Identification, and Characterization of Bacillus strains from the Traditional Korean Soybeanfermented Food, Chungkookjang. J. Appl. Biol. Chem. 50: 202-210

Latha, C. and Nanu, E. 1997. Bacteriological quality of pasteurized milk and its public health significance. Proceedings of the ninth Kerala Science Congress, Kerala, pp. 115-117

Lindsaya, D., Brozelb, V. S., Mosterta, J. F. and Holya, A. V. 2000. Physiology of dairy associated Bacillus spp. over a wide $\mathrm{pH}$ range. Int. J. food microbiol. 54: 49-62

Marth, E.H. and Steele, J.L. 2001. Applied Dairy Microbiology (2 ${ }^{\text {nd }}$ Ed.). Marcel Dekker, New York, pp 1-8 
Meanwell, L. L. 1939. Bacteriology of pasteurized milk. Dairy Ind. 4: 283-287

Mortan, D.R. 2001. Aerobic plate count. Compendium of methods for the microbial examination of foods. (eds. Downes, F.P. and Ito, K.). Fourth edition. American Public Health Association, Washington DC, pp. 63-68

Pelezynska, E. and Libett, K.1995. Analyses of hygienic risk factors and CCP in milking and processing of raw milk for consumption. Medycyna Weterynaryjna. 51: 396-399

Prejit, Nanu, E. and Latha, C. 2007. Microbial quality assurance of milk during production, processing and Marketing. Am. J. Food. Technol. 2: 136-144

Prucha, M. J. and Parfitt, E. H. 1938. High temperature pasteurization. Manual dairy manufacturers conference, University of Illinois, $213 \mathrm{p}$

Quin, J. D. and Burgwald. 1933. High short holding and low long holding. Milk plant monthly. 22(2): 26-30

Rice, E. B. 1960. Hygienic control of dairy equipment. Quensland Agri. J. 12: 457496

Sethulakshmi, C., Jacob, R.R., Nanu, E. and Sunil, B. 2003. Bacterial quality of toned pasteurized milk retailed in and around Thrissur. Poster abstracts of fifth international food convention, 5-8 December 2003, Mysore, India, Abstract: 57
Shaheen, R., Andersson, M.A., Apetroaie, C., Schulz, A., Ehling-Schulz, M., Ollilainen, V.-M., Salkinoja-Salonen, M.S., 2006. Potential of selected infant food formulas for production of Bacillus cereus emetic toxin, cereulide. Int. J. of Food Microbiol. 107: 287-294

Snedecor, G. W. and Cochran, W. G. 1994. Statistical methods ( $8^{\text {th }}$ Ed.). The lowa state university, Ames, Lowa, pp 310315

Tamime, A.Y. 2008. Cleaning in place- dairy foods and beverage operations. Blackwell Science Ltd, Oxford, pp 2-8

Vlkovai, H., Babakai, V., Seydlova, R., Pavliki, I. and Schlegelovai, J. 2008. Biofilms and hygiene on dairy farms and in the dairy industry, sanitation chemical products and their effectiveness on biofilms a review. Czech J. Food Sci., 26: 309-323

Wehr, H.M. and Frank, J.F. 2004. Standard methods for the examination of dairy products $\left(17^{\text {th }}\right.$ Ed.). American Public Health Association, Washington, DC, pp 63-87

Wirtanen G. and Salo S. 2003 Disinfection in food processing, Efficacy testing of disinfectants. Rev. Env. Sci. Biotechnol. 2: 293-306

Yale, M. W. 1933. Bacteriological Studies of a High-Temperature, Short-Time Pasteurizer. N.Y. Tech. Bul. 207p

\section{How to cite this article:}

Amitha Thomas, V. Prasad, P.M. Priya, C.T. Sathian and Geetha, R. 2019. Impact of Recycling Cleaning Solution under Cleaning-In-Place (CIP) System on Thermoduric Count in Pasteurized Milk. Int.J.Curr.Microbiol.App.Sci. 8(06): 1343-1351.

doi: https://doi.org/10.20546/ijcmas.2019.806.162 